Original scientific paper - Izvorni znanstveni rad

UDK: 637.133

\title{
Effect of storage time under home refrigeration conditions on the quality of opened drinking milk
}

\author{
doi: $10.15567 /$ mljekarstvo.2017.0406 \\ Aneta Brodziak ${ }^{*}$, Jolanta Król², Zygmunt Litwińczuk ${ }^{1}$, Agnieszka Zaborska², Tomasz Czernecki \\ ${ }^{1}$ University of Life Sciences in Lublin, \\ Department of Breeding and Protection of Cattle Genetic Resources, \\ Akademicka 13, 20-950 Lublin, Poland \\ ${ }^{2}$ University of Life Sciences in Lublin, \\ Department of Commodity Science and Processing of Raw Animal Materials, \\ Akademicka 13, 20-950 Lublin, Poland \\ ${ }^{3}$ University of Life Sciences in Lublin, \\ Department of Biotechnology, Human Nutrition and Science of Food Commodities, \\ Skromna 8, 20-704 Lublin, Poland \\ Received - Prispjelo: 13.05.2017. \\ Accepted - Prihvaćeno: 27.09.2017.
}

\begin{abstract}
Aim of the study was to determine the effect of the duration of storage of opened drinking milk (pasteurized, micro-filtered and UHT) under home refrigeration conditions on indicators of its freshness (acidity and TBC), nutritional value (contents of fat, protein, lactose, dry matter, nondenatured whey proteins and free fatty acids) and organoleptic characteristics. Refrigeration was found to ensure that opened micro-filtered and pasteurized milk was suitable for consumption for 4 days and UHT milk for at least 7 days. Significant changes in the quality characteristics of protein and fat fractions were not observed until the $7^{\text {th }}$ day of storage. The greatest changes in the content of whey proteins were observed in micro-filtered milk, expressed as decrease of individual proteins of about $20 \%$ each. Pasteurized milk was the most susceptible to lipolysis that resulted in the greatest quantity of saturated free fatty acids. Lipolytic changes affected the acidity of product and thereby led to slight changes in its odor and flavor.
\end{abstract}

Key words: drinking milk, quality, whey proteins, free fatty acids, consumer

\section{Introduction}

Contemporary consumers are paying more and more attention to the quality of the food, which also applies to dairy products, which have become increasingly popular over recent years. Dairy products are characterized by a high nutritional value due to the presence of nutrients such as proteins (especially whey proteins) mono- and polyunsaturated fatty acids which were proved to have a positive effect on the human body. A significant aspect of food production and distribution is ensuring health safety by meeting legal requirements at each stage of production and supply to the consumer, which is known as the "from farm to fork" approach. An important guideline for the consumer is the use-by date, indicating the shelf life of a product stored under ideal conditions. This period largely depends on the quality of the raw material, the technological processes used, and conditions of production, storage, transport and home storage of the final product (Codex Alimentarius, 2009; Szpakowska and Tymoszuk, 2011; Claeys et al., 2014). 
The dairy sector is a significant element of the food market in Poland, with a $13 \%$ share of all sales. Drinking milk accounts for over $50 \%$ of total production of dairy products. It is most often available as pasteurized form (High-Temperature Short-Time (HTST) pasteurization: $72-75^{\circ} \mathrm{C}$ for $15-30$ seconds, or Very High Temperature (VHT) pasteurization: $80-90{ }^{\circ} \mathrm{C}$ for $2-25$ seconds) or as UHT milk (Ultra High Temperature - heated at $132-134^{\circ} \mathrm{C}$ ). A relatively new product on the market is drinking milk produced using the ESL (Extended Shelf Life) technology, involving a combination of microfiltration and pasteurization at a temperature no higher than $75^{\circ} \mathrm{C}$. The aim of heat treatment is to ensure the health safety of the product and to prolong its shelf life. Pasteurization extends shelf life by few days, and ESL by about 21 days; in either case the product must be refrigerated. UHT has the longest shelf life; before the product is opened it can be stored for even months, and this is the only technique that does not require cooling during distribution (Hoffmann et al., 2006). The heat treatment applied may lead to many unfavorable changes. Degradation of lactose to organic acids and generation of lactulose are the most frequently mentioned ones. Moreover, it can contribute to denaturation of whey proteins, destruction of vitamins and enzymes, hydrolysis of proteins and lipids, imbalance in calcium and phosphorus levels, and changes in organoleptic characteristics (Elliott et al., 2005; Lorenzen et al., 2011; Sadooghy-Saraby, 2011; Claeys et al., 2014; Mittal and Bajwa, 2014; Pappas et al., 2015). According to Rodriguez-Alcala et al. (2009) and Pestana et al. (2015), the effect of processing and storage conditions on the protein and lipid profiles of milk from microfiltration, pasteurization and sterilization processes is not fully understood and is subject of controversy, particularly in the case of fatty acids (Rodriguez-Alcala et al., 2009).

Currently there is a growing trend in consumption of dairy products in Poland, although it is still not very high in comparison to the average consumption in the EU (280 L/person/year). In 2014 the total milk consumption, including milk for dairy products, but excluding milk processed into butter, was 205 liters per person (IERiGŻ-PIB, 2015). The dairy product consumption model is clearly dominated by drinking milk (about $40 \mathrm{~L}$ per person), with UHT milk accounting for about $50 \%$ of the total consumption of liquid milk.
According to the information on the package provided by the producer, UHT milk can be stored in a refrigerator after opening for no more than 48 hours, and pasteurized milk for 24 hours. Customers very often do not follow these recommendations, consuming the milk after this time has expired. They judge its quality subjectively on the basis of organoleptic characteristics. However, they are not able to evaluate the actual nutritional value of the product, including the health-promoting properties. Therefore, the aim of the study was to determine the effect of storage time of opened drinking milk in home refrigeration conditions (according to the producer's recommendations) on its nutritional value, microbiological quality, and organoleptic characteristics.

\section{Materials and methods}

\section{Research material}

The subject of the study was commercially available drinking milk with declared fat content of $2 \%$, processed by different methods of heat treatment (pasteurization in high temperature - VHT, UHT and microfiltration - ESL). Milk came from four major manufacturers of drinking milk in Poland (Table 1). In total, 90 milk samples were analysed, including 30 samples of UHT milk, 40 of pasteurized VHT milk and 20 of micro-filtered milk. Samples were taken at the initial date of shelf life i.e. in the first day after production. The product was packaged in $1 \mathrm{~L}$ cartons. The milk was opened on the beginning the study (day "0"), immediately before analysis, and then refrigerated at $4-6{ }^{\circ} \mathrm{C}$ until the end of the study. Milk samples were collected on day 0 and again after 2, 4 and 7 days of storage. Each time, after the carton was opened and $250 \mathrm{~mL}$ were collected, the carton was placed in the refrigerator. That corresponded to the usual behavior of consumers. The study was carried out before the use-by date.

\section{Basic analysis}

In each sample the following parameters were determined: total acidity - titration method according to PN-68/A-86122; active acidity ( $\mathrm{pH}$ value) - by pH-meter CP-401 (Elmetron, Poland); total bacteria count (TBC) in cfu per $\mathrm{mL}$ - according to PN-EN ISO 4833-2:2013-12; and contents of: fat, protein, 
lactose and dry matter, using infrared spectroscopy method by Infrared Milk Analyzer (Bentley Instruments, USA).

\section{Whey proteins}

The content of selected non-denatured whey proteins, i.e. $\alpha$-lactalbumin ( $\alpha$-LA), $\beta$-lactoglobulin $(\beta-\mathrm{LG})$, bovine serum albumin (BSA), lactoferrin and lysozyme was deterimend by a liquid chromatography method (Brodziak et al., 2012). Whey protein separation was performed on liquid chromatography ProStar 210 model and UV-VIS ProStar 325 detector (Varian, USA). The analyses of reference substances were conducted under the same conditions. Using program Star 6.2 Chromatography Workstation (Varian, USA), the qualitative and quantitative identification of each substance was performed followed by their concentration determination. Calibration of the chromatographic system for whey proteins determination was carried out by the external standard method. For this purpose, each protein was calibrated individually by injection solutions of the standards $(20 \mu \mathrm{L})$. Purified proteins, i.e. $\alpha$-LA ( $\geq 85 \%$ ), $\beta$-LG (90\%), bovine albumin serum ( $\geq 96 \%$ ) and lactoferrin (90\%), all from bovine milk as well lysozyme (95 \%) from hen egg white, were purchased from Sigma-Aldrich (Germany). All chemicals were of HPLC analytical grade.

\section{Free fatty acids}

Fatty acid methyl esters (FAME) were prepared in order to determine the amount of free fatty acids in drinking milk. $2 \%(\mathrm{v} / \mathrm{v})$ sulfuric acid in methanol was used as a derivatization reagent. Gas chromatograph (Shimadzu GC2010, Japan) interfaced with a quadrupole mass spectrometer (Shimadzu QP2010Plus, Japan) and autosampler (Shimadzu AOC-20i, Japan) was used. Chromatographic

Table 1. Milk samples grouped by producer

\begin{tabular}{cccc}
\hline $\begin{array}{c}\text { Dairy } \\
\text { code }\end{array}$ & $\begin{array}{c}\text { UHT } \\
\text { milk }\end{array}$ & $\begin{array}{c}\text { Pasteurized } \\
\text { VHT milk }\end{array}$ & $\begin{array}{c}\text { Micro-filtered } \\
\text { milk }\end{array}$ \\
\hline A & 10 & 10 & 10 \\
\hline B & 10 & 10 & - \\
\hline C & - & 10 & 10 \\
\hline D & 10 & 10 & - \\
\hline Total & 30 & 40 & 20 \\
\hline
\end{tabular}

separation was performed by a FactorFour Type VF-5MS capillary column (CP8944, length - $30 \mathrm{~m}$, internal diameter - $0.25 \mathrm{~mm}$, film thickness $0.25 \mu \mathrm{m})$ - Varian, USA. Dispenser heated to a temperature $250{ }^{\circ} \mathrm{C}$ worked in the sample division mode (Split mode - 1:20). The mass spectrometer was operated in the SCAN mode $(40-550 \mathrm{~m} / \mathrm{z})$, with the ion source heated to $250{ }^{\circ} \mathrm{C}$. The flow of carrier gas helium was constant during the analysis (1 $\mathrm{mL} \mathrm{min}^{-1}$ ). Volume of dispensed sample was $0.001 \mathrm{~mL}$. Mass spectra of all the analysed compounds were compared to the reference mass spectra (NIST 5.0), which allowed to determine a similarity coefficient of spectra. Qualitative analysis was performed on the basis of obtained retention times and mass spectra recorded for standards of analysed compounds. Quantitative analysis of FAMEs was performed by external standard method, using 1-bromotetradecane as an internal standard.

\section{Sensory properties}

A sensory evaluation was also performed in laboratory conditions by a suitably prepared team of 10 individuals who had been trained in the sensory evaluation principles. Before the evaluation the samples were coded and kept at room temperature for 1 hour, and then presented to the testers together with a sensory evaluation questionnaire. A 5-point scale was used to evaluate the color intensity and consistency of the products, with 1 designating disqualification (unsuitable) and 5 meaning very good quality (natural, characteristic for the product). Taste and odor were assessed as well (divided into the following characteristics: sweet, milky, cooked, foreign, and overall intensity). In this case a 6-point scale was used: 0 - imperceptible/none, 1 - very weak, 2 - weak, 3 - average, 4 - strong and 5 - very strong.

\section{Statistical analysis}

All analyses were performed in triplicate. The results obtained were analysed statistically using Statistica ver. 9 (Statsoft Inc.), by one-way analysis of variance, distinguishing as a source of variability: producer, type of milk and time of storage. Mean values and standard deviations for certain traits were given in the tables. The significance of differences between mean values was estimated by NIR Fisher's test. 


\section{Results and discussion}

No significant effect of milk producer on the analysed parameters of product during storage was observed. However, there was an effect of milk type and storage time on most of parameters included.

\section{Acidity}

According to Codex Alimentarius (2009), the titratable acidity, microbiological and chemical criteria should be used to detect unacceptable conditions in milk products. Table 2 shows the results of milk freshness evaluation expressed as active ( $\mathrm{pH}$ value) and titratable acidity, and microbiological quality (TBC). Titratable acidity represents the buffering capacity of the milk and indicates any changes in the concentration of acidic compounds in milk, even if the $\mathrm{pH}$ remains unchanged. On the first day of the study, which was the starting point for refrigeration (day 0), these values were consistent with requirements (PN-A-86003/Al:1998) for drinking milk, according to which active acidity $(\mathrm{pH})$ should be 6.6-6.8, and titrimetric acidity 6.0-7.2 ${ }^{\circ} \mathrm{SH}$ for UHT milk and 6.0-7.8 ${ }^{\circ} \mathrm{SH}$ for pasteurized milk. During the storage, a decrease was noted in $\mathrm{pH}$ and an increase in ${ }^{\circ} \mathrm{SH}$, which were statistically significant after 7 days of the storage. The highest titrimetric acidity was noted in the pasteurized milk $\left(8.20^{\circ} \mathrm{SH}\right)$ followed by the micro-filtered milk $\left(7.86^{\circ} \mathrm{SH}\right)$. The least susceptible to changes of these parameters was the UHT milk, in which the acidity values $\mathrm{pH}$ from 6.68 to 6.80 and titrimetric acidity from 6.88 to $7.18^{\circ} \mathrm{SH}$ ) met the requirements of the standard. According to Mika-Mętel (2010), opened UHT milk can be considered fresh in terms of acidity after 5 days-storage under refrigerated conditions without exposure to light. A study by Szpakowska and Tymoszuk (2011) shows that milk can be considered fresh during the 12 days-storage period. Analyzing UHT milk stored at refrigerated conditions whereby the package was opened every day, the authors observed a faster increase in titrimetric acidity after 12 days (from 6.4 to $10.2{ }^{\circ} \mathrm{SH}$ ). In addition, the authors observed that milk with higher fat content became acidified faster. Analyses of pasteurized milk (Danków et al., 2009; Elrahman et al., 2013) confirmed that refrigeration of the product helps to maintain the active and titrimetric acidity within the limits required in Poland, extending its shelf life to a week.

\section{Microbiological quality}

The changes in acidity observed in the present study are linked to the duration of storage and the total bacterial count (Martin et al., 2012, Elrahman et al., 2013). According to PN-A-86003/Al:1998, TBC should not exceed $100.000 \mathrm{cfu} \mathrm{mL}^{-1}$. However, the FDA published in 2015 a Pasteurized Milk Ordinance (PMO) which specifies that grade A pasteurized milk should have an SPC (standard plate count) of $<20,000 \mathrm{cfu} \mathrm{mL}^{-1}$ and a coliform count of $\leq 10 \mathrm{cfu} \mathrm{mL}^{-1}$. In the present study, bacteria were found to multiply as the storage time and titrimetric acidity of the milk increased. The first two days of the study the TBC was at the level of $0 \mathrm{cfu} \mathrm{mL}-1$ for all three milk types. A perceptible increase in this parameter was noted on the fourth day of the study (by 2 or 3 orders of magnitude), and a sharp, statistically significant $(p<0.01)$ increase on the seventh day. On the last day of storage the TBC of the pasteurized and micro-filtered milk, was found to exceed both, Polish norms and American recommendations. This was particularly denoted for pasteurized milk, with a mean TBC of $6.40 \cdot 10^{7} \mathrm{cfu} \mathrm{mL}^{-1}$. Thus we may conclude that refrigeration guarantees micro-filtered and pasteurized milk to be suitable for consumption for 4 days after opening. That period is much longer for UHT milk, i.e. at least 7 days, as indicated by the total bacterial count of $10^{3} \mathrm{cfu} \mathrm{mL}^{-1}$. The UHT technology has a destructive effect on bacterial cells, spore-forming bacteria and spores. During refrigerated storage of the opened product there is an increase in the number and metabolic activity of psychrotrophic bacteria, mainly of the genera Pseudomonas and Bacillus. This leads to accumulation of proteolytic enzymes - proteinases, which can hydrolyze casein to soluble peptides with no signs of overacidity. This effect can be apparent by gelation and bitter flavour (Sorhaug and Stepaniak, 1997; Adamiak et al., 2015).

\section{Nutritional value}

The storage duration of milk had no statistically significant effect on its basic nutrients, i.e. fat, protein, lactose and dry matter contents (Table 3 ). It should be noted that the analysed milk contained about $10 \%$ more fat than the amount stated by the producer, i.e. $2 \%$. It also failed to meet the requirements of Polish standard PN-A-86003/A1:1998, according to which the fat content in milk should not differ by more than $0.05 \%$ from the content stated by the producer. Fat content varied from $2.28 \%$ in 
Table 2. Acidity and microbiological quality of opened drinking milk during refrigerated storage $(\bar{x} \pm$ standard deviation)

\begin{tabular}{|c|c|c|c|}
\hline Day of storage & Active acidity $(\mathrm{pH})$ & Titratable acidity $\left({ }^{\circ} \mathrm{SH}\right)$ & $\mathrm{TBC}^{*}\left(\mathrm{cfu} \mathrm{mL}^{-1}\right)$ \\
\hline \multicolumn{4}{|c|}{ UHT milk } \\
\hline 0 & $6.80^{\mathrm{b}} \pm 0.03$ & $6.88^{a} \pm 0.17$ & $0^{\mathrm{A}}$ \\
\hline 2 & $6.81^{\mathrm{b}} \pm 0.02$ & $6.95^{\mathrm{ab}} \pm 0.14$ & $0^{\mathrm{A}}$ \\
\hline 4 & $6.75^{\mathrm{ab}} \pm 0.21$ & $7.09^{\mathrm{ab}} \pm 0.60$ & $1.55 \cdot 10^{2 \mathrm{~B}}$ \\
\hline 7 & $6.68^{\mathrm{a}} \pm 0.09$ & $7.18^{\mathrm{b}} \pm 0.94$ & $1.04 \cdot 10^{3 \mathrm{C}}$ \\
\hline \multicolumn{4}{|c|}{ Pasteurized VHT milk } \\
\hline 0 & $6.78^{\mathrm{C}} \pm 0.02$ & $7.61^{\mathrm{A}} \pm 0.05$ & $0^{\mathrm{A}}$ \\
\hline 2 & $6.78^{\mathrm{C}} \pm 0.01$ & $7.63^{\mathrm{A}} \pm 0.14$ & $0^{\mathrm{A}}$ \\
\hline 4 & $6.69^{\mathrm{B}} \pm 0.01$ & $7.79^{\mathrm{AB}} \pm 0.56$ & $1.03 \cdot 10^{4 \mathrm{~B}}$ \\
\hline 7 & $6.58^{\mathrm{A}} \pm 0.02$ & $8.20^{\mathrm{B}} \pm 1.09$ & $6.40 \cdot 10^{7 \mathrm{C}}$ \\
\hline \multicolumn{4}{|c|}{ Micro-filtered milk } \\
\hline 0 & $6.84^{\mathrm{B}} \pm 0.03$ & $7.32^{\mathrm{a}} \pm 0.27$ & $0^{\mathrm{A}}$ \\
\hline 2 & $6.78^{\mathrm{B}} \pm 0.11$ & $7.60^{b} \pm 0.42$ & $0^{\mathrm{A}}$ \\
\hline 4 & $6.76^{\mathrm{B}} \pm 0.03$ & $7.59^{b} \pm 0.56$ & $8.54 \cdot 10^{2 \mathrm{~B}}$ \\
\hline 7 & $6.63^{\mathrm{A}} \pm 0.17$ & $7.86^{c} \pm 0.61$ & $1.37 \cdot 10^{5 \mathrm{C}}$ \\
\hline \multicolumn{4}{|c|}{ Factor influence ( $\mathrm{p}$ value) } \\
\hline Type of treatment & 0.294 & 0.051 & 0.010 \\
\hline Day of storage & 0.039 & 0.028 & 0.001 \\
\hline
\end{tabular}

$\mathrm{TBC}^{*}$ - total bacteria count (given as median value)

A, B, a, b - differences between days of storage (in the relations to the start of the study (day " 0 ")) within each milk type;

A, B - significant at $\mathrm{p} \leq 0.01 ; \mathrm{a}, \mathrm{b}$ - significant at $\mathrm{p} \leq 0.05$

Table 3. Content of basic components in opened drinking milk during refrigerated storage ( $\bar{x} \pm$ standard deviation)

\begin{tabular}{|c|c|c|c|c|}
\hline Day of storage & Fat $(\%)$ & Protein $(\%)$ & Lactose (\%) & Dry matter $(\%)$ \\
\hline \multicolumn{5}{|c|}{ UHT milk } \\
\hline 0 & $2.37 \pm 0.00$ & $3.35 \pm 0.00$ & $4.72 \pm 0.01$ & $10.97 \pm 0.02$ \\
\hline 2 & $2.35 \pm 0.00$ & $3.35 \pm 0.01$ & $4.73 \pm 0.01$ & $10.95 \pm 0.01$ \\
\hline 4 & $2.36 \pm 0.01$ & $3.36 \pm 0.01$ & $4.72 \pm 0.01$ & $10.95 \pm 0.02$ \\
\hline 7 & $2.38 \pm 0.01$ & $3.35 \pm 0.01$ & $4.70 \pm 0.01$ & $10.94 \pm 0.02$ \\
\hline \multicolumn{5}{|c|}{ Pasteurized VHT milk } \\
\hline 0 & $2.28 \pm 0.00$ & $3.39 \pm 0.01$ & $4.79 \pm 0.01$ & $11.05 \pm 0.01$ \\
\hline 2 & $2.28 \pm 0.00$ & $3.39 \pm 0.01$ & $4.79 \pm 0.01$ & $11.03 \pm 0.01$ \\
\hline 4 & $2.28 \pm 0.01$ & $3.40 \pm 0.01$ & $4.75 \pm 0.08$ & $11.03 \pm 0.02$ \\
\hline 7 & $2.28 \pm 0.00$ & $3.40 \pm 0.01$ & $4.68 \pm 0.01$ & $10.98 \pm 0.01$ \\
\hline \multicolumn{5}{|c|}{ Micro-filtered milk } \\
\hline 0 & $2.39 \pm 0.01$ & $3.40 \pm 0.01$ & $4.87 \pm 0.01$ & $11.19 \pm 0.01$ \\
\hline 2 & $2.39 \pm 0.02$ & $3.40 \pm 0.01$ & $4.89 \pm 0.01$ & $11.20 \pm 0.01$ \\
\hline 4 & $2.40 \pm 0.01$ & $3.40 \pm 0.01$ & $4.85 \pm 0.01$ & $11.18 \pm 0.01$ \\
\hline 7 & $2.39 \pm 0.01$ & $3.41 \pm 0.01$ & $4.80 \pm 0.01$ & $11.10 \pm 0.01$ \\
\hline \multicolumn{5}{|c|}{ Factor influence ( $\mathrm{p}$ value) } \\
\hline Type of treatment & 0.049 & 0.127 & 0.001 & 0.000 \\
\hline Day of storage & 0.905 & 0.519 & 0.592 & 0.818 \\
\hline
\end{tabular}


the pasteurized milk to $2.39 \%$ in the micro-filtered milk (Table 3). High protein content was found in the pasteurized (3.39\%) and micro-filtered milk (3.40\%). Fetahagić et al. (2002) also found no statistically significant changes in the chemical composition of milk subjected to different heat treatments. According to Siddique et al. (2010), UHT processing leads to lactose degradation and deterioration of the quality of drinking milk. Elrahman et al. (2013) demonstrated a significant $(p<0.001)$ effect of temperature and storage time on the content of fat, lactose and dry matter, while only storage time was found to affect the protein content.

The content of non-denatured whey proteins may be one of the chemical indicators used to evaluate the heat load on milk during processing (Sakkas et al., 2014; Elliott et al., 2005). The amount of native whey proteins (in particular BSA and $\beta-\mathrm{LG}$ ) decreases during heating due to the partial denaturation. In consequence some of them are banded directly to fat globules or interact with $\kappa$-casein. According to Vasbinder et al. (2003), during milk heating at $90{ }^{\circ} \mathrm{C}$ more than $95 \%$ of $\beta$-LG and about $80 \%$ of $\alpha$-LA is denatured. Denaturized whey proteins interact with $\kappa$-casein leading to the so-called whey protein/ $\kappa$-casein complexes (Donato and Guyomarc'h, 2009). Ye et al. (2004) indicated that during the heat treatment of whole milk whey proteins (in particular $\beta$-LG and $\alpha$-LA) bind to milk fat globule membrane proteins via disulfide bonds. The amount of bound proteins increased with an increase in the temperature up to $80{ }^{\circ} \mathrm{C}$, and remained almost constant then. Changes in the whey protein content, however, do not affect the biological value of the product, because these proteins remained the milk - in the form of complexes. Whey proteins have several health-promoting properties, including supporting the functioning of the cardiovascular, digestive and nervous systems and exerting anticancer, antibacterial and antiviral effects (Król et al., 2011; Lisak Jakopović et al., 2016). In our study, the type of heat treatment was found to have a highly significant effect $(p=0.000)$ on the content of non-denatured whey proteins. They were highest in the micro-filtered milk, and lowest in the UHT milk (Table 4). UHT milk contained a four-fold less $\beta$-LG, three-fold less $\alpha$-LA and more than ten-fold less lactoferrin, than ESL milk. Pasteurized (VHT) milk also contained significantly more whey proteins in comparison to UHT milk, i.e. three-fold more $\beta$-LG, two-fold more $\alpha$-LA and eight-fold more lactoferrin. Brodziak et al. (2014) confirmed that the type of heat treatment significantly $(\mathrm{p} \leq 0.05$ and $\mathrm{p} \leq 0.01$ ) influenced the content of non-denatured whey proteins in drinking milk. The most valuable source of whey proteins, particularly lactoferrin and lysozyme, was the micro-filtered milk, which contained $36.21 \mathrm{mg} \mathrm{L}^{-1}$ and $2.93 \mu \mathrm{g} \mathrm{L}^{-1}$, respectively (at $\mathrm{p} \leq 0.01$ ), of these proteins. Lorenzen et al. (2011) found that pasteurized (HTST heated) milk had the highest content of bioactive whey proteins compared to other heat-treated milks. Moatsou (2010) reported that pasteurization of cow, buffalo and camel milk at $65-75{ }^{\circ} \mathrm{C}$ for $30 \mathrm{~min}$ did not significantly reduce lysozyme activity, and only a higher temperature $\left(85^{\circ} \mathrm{C}\right)$ caused a partial inactivation. Claeys et al. (2014) report that only heating at $85{ }^{\circ} \mathrm{C}$ for 30 min leads to total inactivation of lactoferrin. According to Lorenzen et al. (2011), the course of the milk production process may also vary depending on the initial content of whey proteins in the raw milk. This applies in particular to non-denatured $\beta$-LG, which according to Mayer et al. (2009) should constitute a minimum of $10 \%$ of the total milk protein in the case of pasteurization (HTST). Sakkas et al. (2014) report that HTST, peroxidase positive milks contained $>3 \mathrm{~g} \mathrm{~L}^{-1}$ non-denatured $\beta$-LG. At higher temperatures they observed a gradual decrease in the content of non-denatured milk proteins, in particular $\beta$-LG $\left(90{ }^{\circ} \mathrm{C}-1132 \mathrm{mg} \mathrm{g} \mathrm{L}^{-1} ; 100{ }^{\circ} \mathrm{C}\right.$ - $404 \mathrm{mg} \mathrm{g} \mathrm{L}^{-1} ; 130{ }^{\circ} \mathrm{C}-57 \mathrm{mg} \mathrm{g} \mathrm{L}^{-1}$ ). The same tendency was observed by Hammershøj et al. (2010). Using HTST pasteurization $\left(72{ }^{\circ} \mathrm{C} / 15\right.$ seconds), they had a low degree of $\beta$-LG denaturation (2-6\%), whereas at higher temperatures - HTLT (High Temperature/Long Time) pasteurization $\left(85^{\circ} \mathrm{C} / 30\right.$ seconds) the degree of $\beta$-LG denaturation reached $30 \%$.

It is important to ascertain the degree and direction of changes in the content of these proteins in order to accurately evaluate their suitability for monitoring changes taking place during technological processes, as well as during storage of the final product. The present study showed that the micro-filtered milk was the least stable during storage. In this product, during 7 days of storage $\beta$-LG content decreased by $0.59 \mathrm{~g} \mathrm{~L}^{-1}(\mathrm{p}<0.01), \alpha$-LA by $0.20 \mathrm{~g} \mathrm{~L}^{-1}(\mathrm{p}<0.05)$, BSA by $0.10 \mathrm{~g} \mathrm{~L}^{-1}(\mathrm{p}<0.05)$, lactoferrin by $7.43 \mathrm{mg} \mathrm{L}^{-1}$ $(\mathrm{p}<0.01)$ and lysozyme by $0.61 \mu \mathrm{g} \mathrm{L} \mathrm{L}^{-1}(\mathrm{p}<0.01)$. Losses in the proteins analysed were at a level of about $20 \%$, which may have been due to the development of psychrotrophic bacteria producing proteinases. 
Table 4. Non-denatured whey proteins in opened drinking milk during refrigerated storage $(\bar{x} \pm$ standard deviation)

\begin{tabular}{|c|c|c|c|c|c|}
\hline Day of storage & $\begin{array}{l}\beta \text {-lactoglobulin } \\
\left(\mathrm{g} \mathrm{L}^{-1}\right)\end{array}$ & $\begin{array}{l}\alpha \text {-lactalbumin } \\
\left(\mathrm{g} \mathrm{L}^{-1}\right)\end{array}$ & $\begin{array}{l}\text { Bovine serum } \\
\text { albumin - BSA }\left(\mathrm{g} \mathrm{L}^{-1}\right)\end{array}$ & $\begin{array}{l}\text { Lactoferrin } \\
\left(\mathrm{mg} \mathrm{L}^{-1}\right)\end{array}$ & $\begin{array}{l}\text { Lysozyme } \\
\left(\mu \mathrm{g} \mathrm{L}^{-1}\right)\end{array}$ \\
\hline \multicolumn{6}{|c|}{ UHT milk } \\
\hline 0 & $0.56^{\mathrm{b}} \pm 0.04$ & $0.38 \pm 0.03$ & $0.28 \pm 0.02$ & $2.89^{c} \pm 0.25$ & $1.49^{\mathrm{b}} \pm 0.09$ \\
\hline 2 & $0.51^{\mathrm{b}} \pm 0.01$ & $0.34 \pm 0.09$ & $0.27 \pm 0.02$ & $2.64^{\mathrm{bc}} \pm 0.20$ & $1.28^{\mathrm{ab}} \pm 0.27$ \\
\hline 4 & $0.47^{\mathrm{ab}} \pm 0.05$ & $0.33 \pm 0.01$ & $0.26 \pm 0.03$ & $2.48^{\mathrm{b}} \pm 0.44$ & $1.2^{\mathrm{a} a} \pm 0.06$ \\
\hline 7 & $0.45^{\mathrm{a}} \pm 0.07$ & $0.31 \pm 0.01$ & $0.24 \pm 0.01$ & $2.26^{a} \pm 0.22$ & $1.25^{\mathrm{a}} \pm 0.15$ \\
\hline \multicolumn{6}{|c|}{ Pasteurized VHT milk } \\
\hline 0 & $1.63 \pm 0.02$ & $0.66 \pm 0.04$ & $0.29^{b} \pm 0.02$ & $22.87^{\mathrm{B}} \pm 0.92$ & $2.64^{\mathrm{b}} \pm 0.14$ \\
\hline 2 & $1.61 \pm 0.03$ & $0.58 \pm 0.04$ & $0.22^{\mathrm{ab}} \pm 0.01$ & $20.55^{\mathrm{AB}} \pm 1.88$ & $2.59^{\mathrm{ab}} \pm 0.10$ \\
\hline 4 & $1.53 \pm 0.04$ & $0.59 \pm 0.02$ & $0.20^{\mathrm{ab}} \pm 0.01$ & $16.64^{\mathrm{A}} \pm 0.55$ & $2.38^{\mathrm{ab}} \pm 0.27$ \\
\hline 7 & $1.52 \pm 0.05$ & $0.59 \pm 0.01$ & $0.19^{\mathrm{a}} \pm 0.01$ & $15.21^{\mathrm{A}} \pm 0.44$ & $2.07^{\mathrm{a}} \pm 0.41$ \\
\hline \multicolumn{6}{|c|}{ Micro-filtered milk } \\
\hline 0 & $2.23^{\mathrm{B}} \pm 0.10$ & $0.92^{\mathrm{b}} \pm 0.04$ & $0.42^{\mathrm{b}} \pm 0.03$ & $36.21^{\mathrm{B}} \pm 0.49$ & $2.93^{\mathrm{b}} \pm 0.31$ \\
\hline 2 & $2.15^{\mathrm{AB}} \pm 0.05$ & $0.86^{\mathrm{b}} \pm 0.06$ & $0.39^{b} \pm 0.01$ & $32.89^{\mathrm{AB}} \pm 0.55$ & $2.58^{\mathrm{ab}} \pm 0.23$ \\
\hline 4 & $1.99^{\mathrm{AB}} \pm 0.16$ & $0.81^{\mathrm{a}} \pm 0.02$ & $0.35^{\mathrm{ab}} \pm 0.01$ & $31.25^{\mathrm{AB}} \pm 0.66$ & $2.44^{\mathrm{ab}} \pm 0.25$ \\
\hline 7 & $1.64^{\mathrm{A}} \pm 0.08$ & $0.72^{\mathrm{a}} \pm 0.01$ & $0.32^{\mathrm{a}} \pm 0.02$ & $28.78^{\mathrm{A}} \pm 1.98$ & $2.32^{\mathrm{a}} \pm 0.51$ \\
\hline \multicolumn{6}{|c|}{ Factor influence ( $\mathrm{p}$ value) } \\
\hline Type of treatment & 0.000 & 0.000 & 0.000 & 0.000 & 0.000 \\
\hline Day of storage & 0.004 & 0.035 & 0.040 & 0.002 & 0.018 \\
\hline
\end{tabular}

A, B, a, b - differences between days of storage (in the relations to the start of the study (day " 0 ")) within each milk type;

A, B - significant at $\mathrm{p} \leq 0.01 ; \mathrm{a}, \mathrm{b}$ - significant at $\mathrm{p} \leq 0.05$

Table 5. Content of selected short- and medium-chain free fatty acids in opened drinking milk during refrigerated storage $\left(\mathrm{mg} \mathrm{L}^{-1}\right)(\bar{x} \pm$ standard deviation $)$

\begin{tabular}{|c|c|c|c|c|c|c|c|}
\hline $\begin{array}{l}\text { Day of } \\
\text { storage }\end{array}$ & $\begin{array}{c}\text { Butyric acid } \\
\text { (C4:0) }\end{array}$ & $\begin{array}{c}\text { Caproic acid } \\
\text { (C6:0) }\end{array}$ & $\begin{array}{c}\text { Caprylic acid } \\
\text { (C8:0) }\end{array}$ & $\begin{array}{c}\text { Capric acid } \\
(\mathrm{Cl0:0})\end{array}$ & $\begin{array}{c}\text { Lauric acid } \\
(\mathrm{Cl} 2: 0)\end{array}$ & $\begin{array}{l}\text { Myristic acid } \\
(\mathrm{Cl} 4: 0)\end{array}$ & Sum \\
\hline \multicolumn{8}{|c|}{ UHT milk } \\
\hline 0 & $0.114^{\mathrm{a}} \pm 0.002$ & $0.075 \pm 0.001$ & $0.059 \pm 0.001$ & $0.110^{\mathrm{a}} \pm 0.001$ & $0.151^{\mathrm{A}} \pm 0.004$ & $0.424 \pm 0.009$ & $0.933^{\mathrm{a}}$ \\
\hline 2 & $0.110^{\mathrm{a}} \pm 0.003$ & $0.077 \pm 0.002$ & $0.062 \pm 0.002$ & $0.117^{b} \pm 0.002$ & $0.157^{\mathrm{A}} \pm 0.004$ & $0.433 \pm 0.012$ & $0.956^{\mathrm{a}}$ \\
\hline 4 & $0.110^{\mathrm{a}} \pm 0.001$ & $0.079 \pm 0.003$ & $0.063 \pm 0.002$ & $0.118^{\mathrm{b}} \pm 0.002$ & $0.157^{\mathrm{A}} \pm 0.005$ & $0.438 \pm 0.006$ & $0.956^{\mathrm{a}}$ \\
\hline 7 & $0.127^{b} \pm 0.004$ & $0.084 \pm 0.002$ & $0.067 \pm 0.003$ & $0.121^{\mathrm{b}} \pm 0.002$ & $0.172^{\mathrm{B}} \pm 0.005$ & $0.448 \pm 0.009$ & $1.019^{\mathrm{b}}$ \\
\hline \multicolumn{8}{|c|}{ Pasteurized VHT milk } \\
\hline 0 & $0.102 \pm 0.002$ & $0.070^{\mathrm{a}} \pm 0.002$ & $0.056 \pm 0.004$ & $0.109^{\mathrm{A}} \pm 0.003$ & $0.152 \pm 0.006$ & $0.405 \pm 0.009$ & $0.894^{\mathrm{a}}$ \\
\hline 2 & $0.100 \pm 0.003$ & $0.072^{\mathrm{a}} \pm 0.004$ & $0.059 \pm 0.002$ & $0.116^{\mathrm{AB}} \pm 0.008$ & $0.156 \pm 0.002$ & $0.413 \pm 0.011$ & $0.916^{\mathrm{a}}$ \\
\hline 4 & $0.103 \pm 0.001$ & $0.074^{\mathrm{a}} \pm 0.003$ & $0.060 \pm 0.002$ & $0.119^{\mathrm{AB}} \pm 0.006$ & $0.162 \pm 0.005$ & $0.435 \pm 0.008$ & $0.953^{\text {bc }}$ \\
\hline 7 & $0.112 \pm 0.003$ & $0.083^{\mathrm{b}} \pm 0.002$ & $0.063 \pm 0.002$ & $0.126^{\mathrm{B}} \pm 0.006$ & $0.158 \pm 0.004$ & $0.439 \pm 0.004$ & $0.981^{\mathrm{c}}$ \\
\hline \multicolumn{8}{|c|}{ Micro-filtered milk } \\
\hline 0 & $0.100^{\mathrm{A}} \pm 0.006$ & $0.072^{\mathrm{a}} \pm 0.002$ & $0.059^{\mathrm{a}} \pm 0.003$ & $0.116^{\mathrm{A}} \pm 0.001$ & $0.157 \pm 0.006$ & $0.435 \pm 0.011$ & $0.939^{\mathrm{a}}$ \\
\hline 2 & $0.110^{\mathrm{A}} \pm 0.004$ & $0.078^{\mathrm{ab}} \pm 0.003$ & $0.063^{\mathrm{a}} \pm 0.003$ & $0.116^{\mathrm{A}} \pm 0.003$ & $0.162 \pm 0.05$ & $0.445 \pm 0.008$ & $0.974^{\mathrm{b}}$ \\
\hline 4 & $0.116^{\mathrm{AB}} \pm 0.005$ & $0.077^{\mathrm{ab}} \pm 0.002$ & $0.061^{\mathrm{a}} \pm 0.001$ & $0.122^{\mathrm{A}} \pm 0.004$ & $0.159 \pm 0.004$ & $0.446 \pm 0.007$ & $0.981^{b}$ \\
\hline 7 & $0.121^{\mathrm{B}} \pm 0.002$ & $0.083^{\mathrm{b}} \pm 0.003$ & $0.069^{\mathrm{b}} \pm 0.002$ & $0.131^{\mathrm{B}} \pm 0.005$ & $0.166 \pm 0.003$ & $0.454 \pm 0.006$ & $1.024^{c}$ \\
\hline \multicolumn{8}{|c|}{ Factor influence (p value) } \\
\hline $\begin{array}{c}\text { Type of } \\
\text { treatment }\end{array}$ & 0.049 & 0.393 & 0.343 & 0.560 & 0.665 & 0.081 & 0.271 \\
\hline $\begin{array}{l}\text { Day of } \\
\text { storage }\end{array}$ & 0.044 & 0.023 & 0.164 & 0.004 & 0.058 & 0.127 & 0.012 \\
\hline
\end{tabular}

A, B, a, b - differences between days of storage (in the relations to the start of the study (day " 0 ")) within each milk type;

A, B - significant at $\mathrm{p} \leq 0.01 ; \mathrm{a}, \mathrm{b}$ - significant at $\mathrm{p} \leq 0.05$ 


\section{Free fatty acids}

Milk fat exists as fat globules emulsified in the aqueous phase of milk. The interior of the fat globules is filled with triacylglycerols, accounting for $98 \%$ of the milk fat. Milk fat globule membrane consists of glycoproteins, phospholipids, sterols and fat-soluble vitamins, whereas the interior contains also monoand diaglycerols and free fatty acids (FFA). FFA constitute $0.1-0.4 \%$ of the fat of raw cow milk. However, in the processed milks only traces of FFA are detected (Jensen, 1995).

Triacylglycerols in fresh milk are protected from the effects of lipases by the fat globule membrane. Lipolysis of triacylglycerols arises from damage to the membrane e.g. due to fluctuations in storage temperature or agitation of the raw milk on the farm or during transport or heat treatment (SadooghySaraby, 2011). Lipolysis in milk can be induced by natural lipases, such as LPL, which is completely inactivated by the HTST heat treatment $\left(72{ }^{\circ} \mathrm{C} / 15 \mathrm{~s}\right)$, or by lipases from psychrotrophic bacteria, which are thermoresistant at pasteurization temperatures and even to UHT treatment (Deeth and Fitz-Gerald,
2006). Lipolysis leads to hydrolysis of triacylglycerols and to the generation of FFA, and partially of glycerides and glycerol. Factors determining the lipolysis process in drinking milk include the type of heat treatment and storage time (Kaufmann et al., 2009, Lorenzen et al., 2011).

\section{Whey proteins}

Tables 5-7 present the content of selected short-, medium- and long-chain free fatty acids in the analysed milk samples. Sums of these acids are presented in the Table 8 . The results clearly show that content of FFA varied depending on the type of milk. The pasteurized milk had the least shortand medium-chain and saturated FFA (Tables 5 and 6), while the UHT milk contained the fewest longchain unsaturated FFA (Table 7). The $p$ value obtained indicates that the heat treatment significantly affected the quantity of these acids (Tables 5-8). It is worth noting that the pasteurized milk had more arachidonic, linolelaidic and gamma-linolenic acids than the UHT milk, by $43 \%$ (at $\mathrm{p}=0.002$ ), $36 \%$ (at $\mathrm{p}=0.000$ ) and $35 \%$ (at $\mathrm{p}=0.000$ ), respectively.

Table 6. Content of selected long-chain saturated free fatty acids in opened drinking milk during refrigerated storage $\left(\mathrm{mg} \mathrm{L}^{-1}\right)(\bar{x} \pm$ standard deviation $)$

\begin{tabular}{|c|c|c|c|c|c|c|}
\hline $\begin{array}{l}\text { Day of } \\
\text { storage }\end{array}$ & $\begin{array}{l}\text { Pentadecanoic } \\
\text { acid (C15:0) }\end{array}$ & $\begin{array}{l}\text { Palmitic acid } \\
\text { (C16:0) }\end{array}$ & $\begin{array}{c}\text { Heptadecanoic } \\
\text { acid }(\mathrm{Cl} 7: 0)\end{array}$ & $\begin{array}{l}\text { Stearic acid } \\
\text { (C18:0) }\end{array}$ & $\begin{array}{l}\text { Arachidonic acid } \\
\text { (C20:0) }\end{array}$ & Sum \\
\hline \multicolumn{7}{|c|}{ UHT milk } \\
\hline 0 & $0.096^{\mathrm{A}} \pm 0.004$ & $1.082 \pm 0.018$ & $0.058^{\mathrm{A}} \pm 0.001$ & $0.522 \pm 0.008$ & $0.016^{\mathrm{A}} \pm 0.002$ & 1.774 \\
\hline 2 & $0.094^{\mathrm{A}} \pm 0.002$ & $1.066 \pm 0.014$ & $0.061^{\mathrm{A}} \pm 0.003$ & $0.518 \pm 0.012$ & $0.017^{\mathrm{A}} \pm 0.001$ & 1.756 \\
\hline 4 & $0.098^{\mathrm{A}} \pm 0.003$ & $1.106 \pm 0.017$ & $0.058^{\mathrm{A}} \pm 0.003$ & $0.541 \pm 0.013$ & $0.016^{\mathrm{A}} \pm 0.001$ & 1.819 \\
\hline 7 & $0.109^{\mathrm{B}} \pm 0.003$ & $1.119 \pm 0.013$ & $0.072^{\mathrm{B}} \pm 0.004$ & $0.553 \pm 0.014$ & $0.025^{\mathrm{B}} \pm 0.004$ & 1.878 \\
\hline \multicolumn{7}{|c|}{ Pasteurized VHT milk } \\
\hline 0 & $0.089^{\mathrm{A}} \pm 0.002$ & $1.051^{\mathrm{a}} \pm 0.012$ & $0.053^{\mathrm{A}} \pm 0.001$ & $0.481 \pm 0.008$ & $0.014^{\mathrm{A}} \pm 0.001$ & 1.688 \\
\hline 2 & $0.090^{\mathrm{A}} \pm 0.002$ & $1.050^{\mathrm{a}} \pm 0.014$ & $0.052^{\mathrm{A}} \pm 0.001$ & $0.477 \pm 0.011$ & $0.013^{\mathrm{A}} \pm 0.001$ & 1.682 \\
\hline 4 & $0.096^{\mathrm{A}} \pm 0.003$ & $1.105^{\mathrm{b}} \pm 0.008$ & $0.056^{\mathrm{A}} \pm 0.002$ & $0.505 \pm 0.014$ & $0.015^{\mathrm{A}} \pm 0.002$ & 1.777 \\
\hline 7 & $0.111^{\mathrm{B}} \pm 0.004$ & $1.124^{\mathrm{c}} \pm 0.011$ & $0.068^{\mathrm{B}} \pm 0.004$ & $0.515 \pm 0.012$ & $0.021^{\mathrm{B}} \pm 0.002$ & 1.839 \\
\hline \multicolumn{7}{|c|}{ Micro-filtered milk } \\
\hline 0 & $0.092^{\mathrm{a}} \pm 0.004$ & $1.133 \pm 0.011$ & $0.060^{\mathrm{a}} \pm 0.002$ & $0.527 \pm 0.007$ & $0.017^{\mathrm{A}} \pm 0.002$ & 1.829 \\
\hline 2 & $0.094^{\mathrm{a}} \pm 0.007$ & $1.146 \pm 0.014$ & $0.061^{\mathrm{a}} \pm 0.001$ & $0.537 \pm 0.011$ & $0.018^{\mathrm{A}} \pm 0.001$ & 1.856 \\
\hline 4 & $0.093^{\mathrm{a}} \pm 0.003$ & $1.159 \pm 0.012$ & $0.062^{\mathrm{a}} \pm 0.002$ & $0.543 \pm 0.006$ & $0.018^{\mathrm{A}} \pm 0.002$ & 1.875 \\
\hline 7 & $0.104^{\mathrm{b}} \pm 0.002$ & $1.169 \pm 0.009$ & $0.068^{\mathrm{b}} \pm 0.003$ & $0.553 \pm 0.008$ & $0.027^{\mathrm{B}} \pm 0.003$ & 1.921 \\
\hline \multicolumn{7}{|c|}{ Factor influence (p value) } \\
\hline $\begin{array}{l}\text { Type of } \\
\text { treatment }\end{array}$ & 0.800 & 0.012 & 0.407 & 0.050 & 0.394 & 0.167 \\
\hline $\begin{array}{l}\text { Day of } \\
\text { storage }\end{array}$ & 0.000 & 0.356 & 0.011 & 0.419 & 0.004 & 0.044 \\
\hline
\end{tabular}

A, B , a b - differences between days of storage (in the relations to the start of the study (day " 0 ")) within each milk type; A, B - significant at $\mathrm{p} \leq 0.01 ; \mathrm{a}, \mathrm{b}$ - significant at $\mathrm{p} \leq 0.05$ 


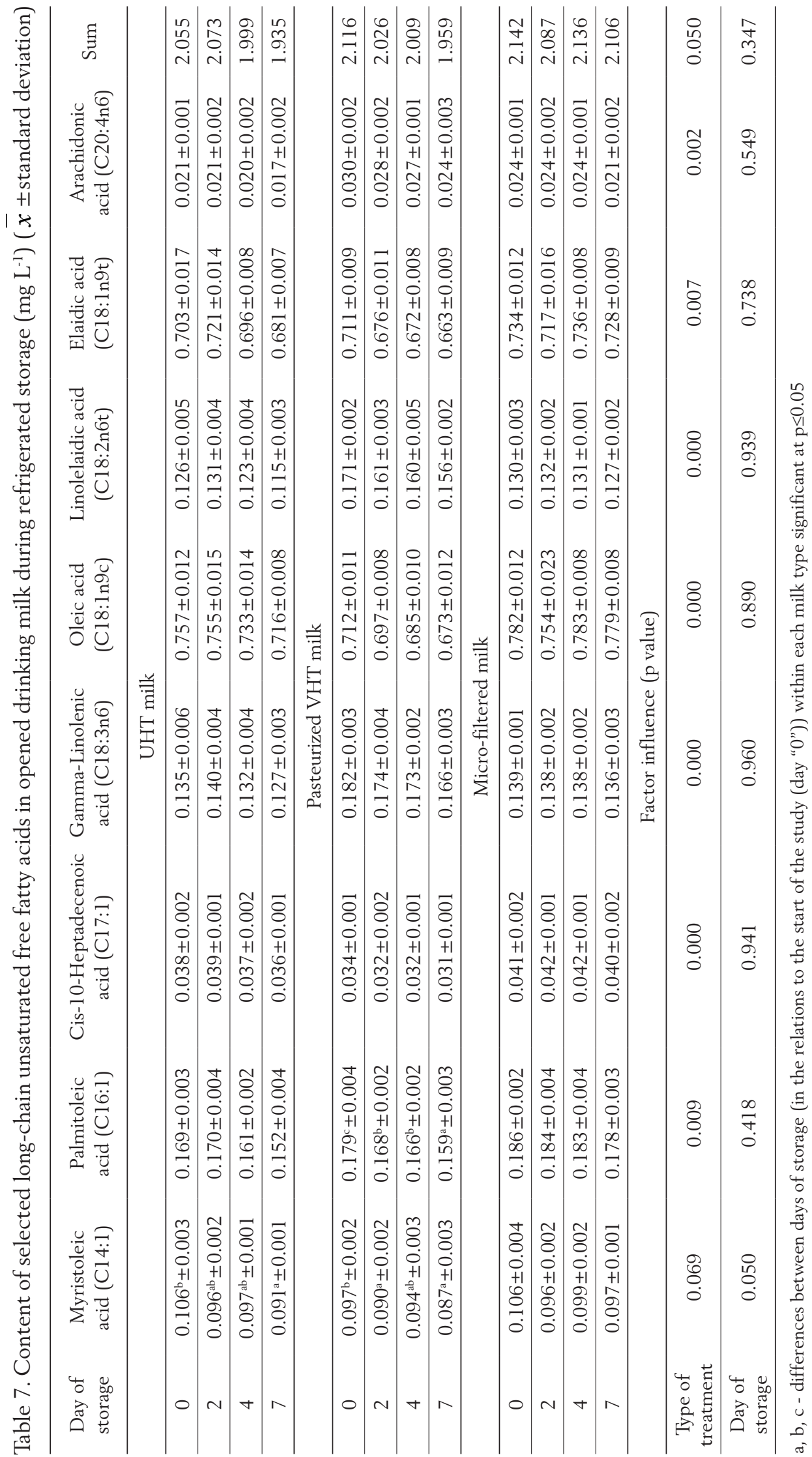


Our results correspond to studies by other authors (Pereda et al., 2008; Kaufmann et al., 2009; Lorenzen et al., 2011), who have also found that the type of heat treatment affects the content of components of the lipid fraction in milk. However, according to Herzallah et al. (2005), the type of heat treatment, except for microwave radiation, is not a statistically significant factor determining the content of acids in milk and dairy products.

Analysis of variance of FFA content considering on the duration of refrigeration of opened milk showed that the quantity of saturated acids increased, while that of unsaturated acids decreased (Tables 5-8). This indicates intensification of lipolysis over storage time. In most cases the greatest changes in the content of the free acids analysed were noted in the pasteurized milk. In the case of a

Table 8. Sums of content of free fatty acids in opened drinking milk during refrigerated storage $\left(\mathrm{mg} \mathrm{L}^{-1}\right)$

\begin{tabular}{|c|c|c|c|}
\hline $\begin{array}{l}\text { Day of } \\
\text { storage }\end{array}$ & All FFA & SFFA & PUFFA \\
\hline \multicolumn{4}{|c|}{ UHT milk } \\
\hline 0 & 4.762 & 2.707 & 2.055 \\
\hline 2 & 4.785 & 2.712 & 2.073 \\
\hline 4 & 4.783 & 2.784 & 1.999 \\
\hline 7 & 4.832 & 2.897 & 1.935 \\
\hline \multicolumn{4}{|c|}{ Pasteurized VHT milk } \\
\hline 0 & 4.698 & $2.582^{\mathrm{a}}$ & 2.116 \\
\hline 2 & 4.624 & $2.598^{\mathrm{a}}$ & 2.026 \\
\hline 4 & 4.739 & $2.730^{\mathrm{b}}$ & 2.009 \\
\hline 7 & 4.779 & $2.820^{c}$ & 1.959 \\
\hline \multicolumn{4}{|c|}{ Micro-filtered milk } \\
\hline 0 & 4.910 & 2.768 & 2.142 \\
\hline 2 & 4.917 & 2.830 & 2.087 \\
\hline 4 & 4.992 & 2.856 & 2.136 \\
\hline 7 & 5.051 & 2.945 & 2.106 \\
\hline \multicolumn{4}{|c|}{ Factor influence ( $\mathrm{p}$ value) } \\
\hline $\begin{array}{c}\text { Type of } \\
\text { treatment }\end{array}$ & 0.001 & 0.087 & 0.050 \\
\hline $\begin{array}{l}\text { Day of } \\
\text { storage }\end{array}$ & 0.740 & 0.048 & 0.347 \\
\hline $\begin{array}{l}\text { a, b, c - differen } \\
\text { start of the stud } \\
\text { p } \leq 0.05 \\
\text { FFA - free fatty } \\
\text { SFFA - saturate } \\
\text { PUFA - polyun }\end{array}$ & $\begin{array}{l}\text { between da } \\
\text { day "0")) wi } \\
\text { ids } \\
\text { ree fatty aci } \\
\text { lrated free }\end{array}$ & $\begin{array}{l}\text { orage (in } \\
\text { ch milk ty } \\
\text { ids }\end{array}$ & $\begin{array}{l}\text { lations to th } \\
\text { nificant at }\end{array}$ \\
\hline
\end{tabular}

7-day period of refrigeration, the greatest differences (an increase of over $30 \%$ ) were found in the content of free arachidonic acid (C20:0), irrespective of the type of heat treatment. On the other hand, oleic acid, decreased the least (Table 7).

Pereda et al. (2008) found no statistically significant differences in the content of FFA in pasteurized milk during a 7-day storage, although the quantity of these acids decreased slightly. Lorenzen et al. (2011) reported that micro-filtered ESL milk exhibits a lower heat load than ESL heated at a high temperature (pasteurized), resulting in an increase in residual lipase activity, which may accelerate the generation of FFA during prolonged storage.

Moreover, many authors (Elliott et al., 2005, Lorenzen et al., 2011, Sadooghy-Saraby, 2011, Pestana et al., 2015) demonstrated that lipolysis occurs during storage and the release of free fatty acids and triglycerides give rise to sensory defects, and in particular to a rancid taste, also described as bitter, impure or soapy. A high level of FFA in dairy products also causes a sour aftertaste, undoubtedly also linked to the change in acidity. According to Kaufmann et al. (2009), an increase in FFA of about $1.3 \mu \mathrm{mol} / \mathrm{mL}$ during 21 -day storage is accompanied by a potential increase of acidity by $0.5^{\circ} \mathrm{SH}$.

The type of the present microbes also plays an important role, since they are involved in microbiological lipolysis leading to rancidity in the product. Thereby psychrotrophic bacteria, yeasts and molds are usually present in raw milk and in refrigerated products. The appearance of sensory defects, mainly a sour aftertaste, is linked to a large number of

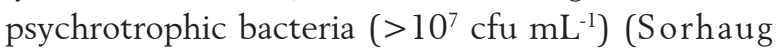
and Stepaniak, 1997; Pereda et al., 2008; Adamiak et al., 2015).

\section{Sensory properties}

Another effect of changes taking place during heat treatment of milk is alteration of its organoleptic properties, particularly the appearance of a cooked taste (Figures la-d). According to the obtained results, the UHT milk, i.e. the product subjected to treatment at the highest temperature, was assigned by the highest possible score (5.0) for cooked odor and taste (Figure la). These characteristics received the lowest scores in the micro-filtered milk. It should be noted that the micro-filtered milk 
had the lowest sweet taste and smell. Lorenzen et al. (2011), observed a tendency for HTST-heated milk and micro-filtered ESL milk to have a 'milky' odor and taste. The authors found that the sensory properties of the micro-filtered and pasteurized milk were comparable, with is consistent with the results of our study.

During the 7-day storage period changes in the sensory scores of the products were small and acceptable to the testers (Figures la-d). The cooked taste and odor were less detectable to the testers only in samples of UHT milk at the $7^{\text {th }}$ day of storage (Figure 1d). No changes in the color and consistency

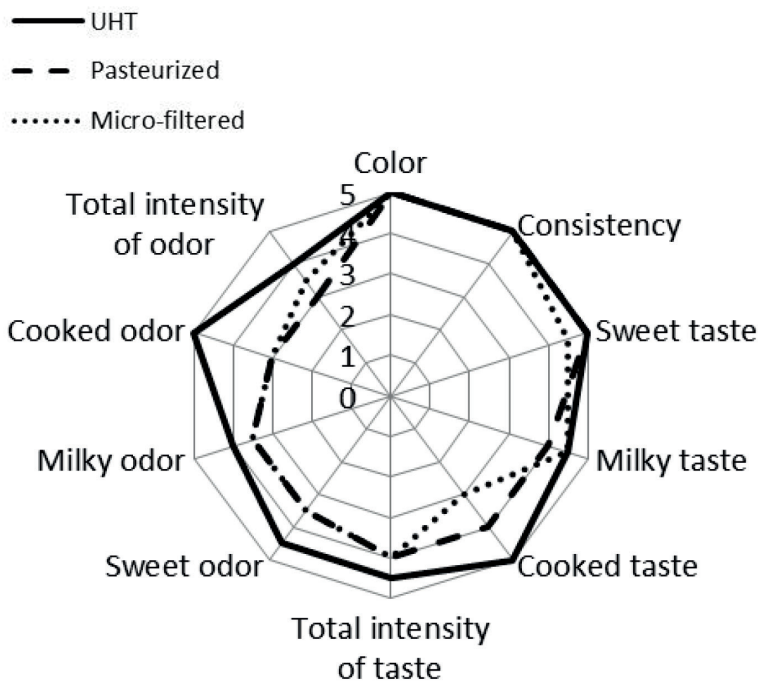

Fig. 1a. Results of sensory analysis in the day " 0 " (the start of the study)

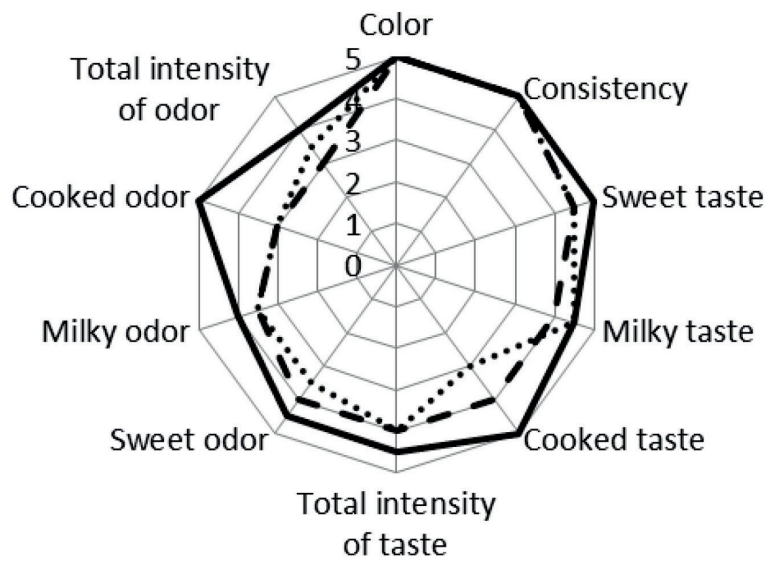

Fig. 1c. Results of sensory analysis in the $4^{\text {th }}$ day of storage of the products were observed in relation to the type of milk and the duration of refrigeration. There was also no foreign odor or taste in both initial and stored milk samples. The slight changes observed in odor and taste in the micro-filtered and pasteurized milk may be linked to slight lipolytic changes, and to acidity, which despite statistically significant differences was not abnormal. In the study by Szpakowska and Tymoszuk (2011), the flavor and odor characteristics and consistency of UHT milk were acceptable after daily opening for 8 days and that they remained acceptable for longer time in milk with lower fat content.

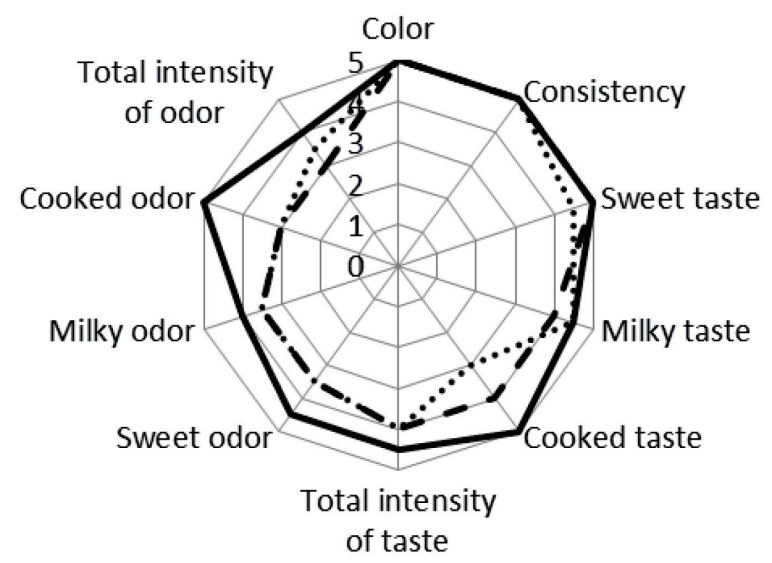

Fig. 1b. Results of sensory analysis in the $2^{\text {nd }}$ day of storage

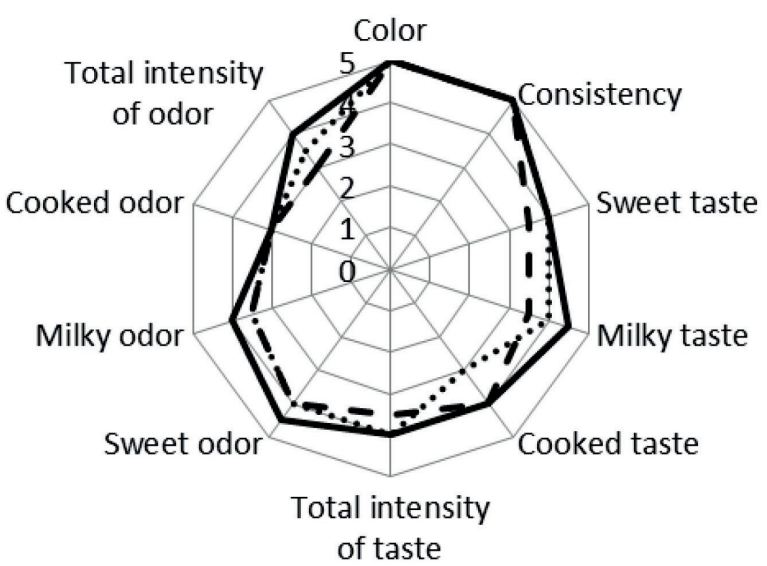

Fig. 1d. Results of sensory analysis in the $7^{\text {th }}$ day of storage

Figure 1. Results of sensory analysis of opened drinking milk at the day "0" (a), at $2^{\text {nd }}$ day (b), at $4^{\text {th }}$ day (c), and at $7^{\text {th }}$ day (d) of refrigerated storage 


\section{Conclusions}

In conclusion, storage of drinking milk at low temperature delays the development of bacteria that have survived heat treatment as well as those resulting from reinfection due to repeated package opening by the consumer. Under these conditions milk can be consumed throughout 4 days in the case of micro-filtered or pasteurized milk, and at least 7 days in the case of UHT. Significant quantitative changes in characteristics of whey proteins and free fatty acids of the milk, while the content of basic nutrients was steady, were observed at the $7^{\text {th }}$ day of storage. During this time the changes in the sensory score of the products were small and acceptable to the testers. The changes observed in the quality of opened milk stored in refrigerated conditions showed that irrespective of the type of heat treatment the product retained its freshness longer than stated on the package. However, because distribution conditions and storage of the opened product by the consumer cannot be monitored, producers recommend a shorter storage time, i.e. no longer than $24 \mathrm{~h}$ (pasteurized) or $48 \mathrm{~h}$ (UHT).

\section{Kvaliteta otvorenog konzumnog mlijeka tijekom hladnog skladištenja u kućanstvu}

\section{Sažetak}

Cilj istraživanja bio je utvrditi učinak trajanja skladištenja otvorenog konzumnog mlijeka (pasterizirano, mikrofiltrirano i UHT) u uvjetima hlađenja u kućanstvu na pokazatelje njegove svježine (kiselost, ukupan broj bakterija), nutritivnu vrijednost (sadržaj masti, proteina, laktoze, suhe tvari, ne-denaturiranih proteina sirutke i slobodnih masnih kiselina) i organoleptička svojstva. Hlađenje je pokazalo da je otvoreno mikrofiltrirano i pasterizirano mlijeko prikladno za konzumaciju 4 dana, a UHT mlijeko najmanje 7 dana. Značajne promjene u svojstvima kvalitete proteina i frakcija masti nisu bile utvrđene do 7 . dana skladištenja. Najveće promjene u sadržaju proteina sirutke utvrđene su u mikrofiltriranom mlijeku, što se očitovalo kroz smanjenje udjela pojedinih frakcija proteina u iznosu od $20 \%$. Pasterizirano mlijeko bilo je najosjetljivije na lipolizu, što je rezultiralo najvećom količinom slobodnih zasićenih masnih kiselina. Lipolitičke promjene utjecale su na kiselost proizvoda i time dovele do neznatnih promjena $u$ njezinom mirisu i okusu.

\section{Ključne riječi: konzumno mlijeko, kvaliteta, proteini sirutke, slobodne masne kiseline, potrošači}

\section{References}

1. Adamiak, A., Górska, A., Mróz, B. (2015): Psychrotrophic bacteria in raw milk and dairy products. Żywność. Nauka. Technologia. Jakość 101 (4), 36-48.

2. Brodziak, A., Barłowska, J., Król, J., Litwińczuk, Z. (2012): Effect of breed and feeding system on content of selected whey proteins in cow's milk in spring-summer and autumn-winter seasons. Annals of Animal Science 12 (2), 261-269. https://doi.org/10.2478/v10220-012-0022-6

3. Brodziak, A., Król, J., Litwińczuk, Z. (2014): Evaluation of content of protein fraction components in different types of drinking milk. In Properties of food products and raw materials. Selected Issues, (T. Tarko, A. DudaChodak, M. Witczak et al., eds.), pp. 4-14, Oddział Małopolski Polskiego Towarzystwa Technologów Żywności Publishing, Kraków.

4. Claeys, WL., Verraes, C., Cardoen, S., De Block, J., Huyghebaert, A., Raes, K., Dewettinck, K., Herman, L. (2014): Consumption of raw or heated milk from different species: An evaluation of the nutritional and potential health benefits. Food Control 42, 188-201. https://doi.org/10.1016/j.foodcont.2014.01.045

5. Codex Alimentarius (2009): International Food Standards. Code of Hygienic Practice for Milk and Milk Products. No CAC/RCP 57-2004, modified in 2009.

6. Danków, R., Cais-Sokolińska, D., Pikul, J. (2009): Characteristics of pasteurized milk after enzymatic hydrolization of lactose. Nauka Przyroda Technologie 3 (4), 126-130.

7. Deeth, HC., Fitz-Gerald, CH. (2006): Lipolytic enzymes and hydrolytic rancidity. In Advanced Dairy Chemistry, Vol. 2: Lipids, $3^{\text {rd }}$ edn., (Fox, PF., McSweeney, PLH., eds.), Springer, New York, pp. 481-554. https://doi.org/10.1007/0-387-28813-9_15

8. Donato, L., Guyomarc'h, F. (2009): Formation and properties of the whey protein/ $\kappa$-casein complexes in heated skim milk - A review. Dairy Science and Technology 89, 3-29. https://doi.org/10.1051/dst:2008033

9. Elliott, AJ., Datta, N., Amenu, B., Deeth, HC. (2005): Heat-induced and other chemical changes in commercial UHT milks. Journal of Dairy Research 72 (4), 442-446. https://doi.org/10.1017/S002202990500138X 
10. Elrahman, SMAA., Ahmed, AMEMS., Zubeir, IEYME., Owni, OAOE., Ahmed, MKA. (2013): Effect of storage temperature on the microbiological and physicochemical properties of pasteurized milk. Annals. Food Science and Technology 14, 115-121.

11. FDA (2015): Grade "A" Pasteurized Milk Ordinance, Including provisions from the Grade "A" Condensed and Dry Milk Products and Condensed and Dry Whey - Supplement I to the Grade "A" Pasteurized Milk Ordinance. Public Health Service/Food and Drug Administration. Revision.

12. Fetahagić, S., Maćej, O., Djurdjević, J.D., Jovanović, S. (2002): The influence of GDL concentration on milk $\mathrm{pH}$ change during acid coagulation. Journal of Agricultural Science 4, 775-785. https://doi.org/10.2298/JAS0201075F

13. Hammershǿj, M., Hougaard, A.B., Vestergaard, JS., Poulsen, O., Ipsen, RH. (2010): Instant infusion pasteurization of bovine milk. II. Effects on indigenous milk enzymes activity and whey protein denaturation. International Journal of Dairy Technology 63, 197-208. https://doi.org/10.1111/j.1471-0307.2010.00583.x

14. Herzallah, S.M., Humeid, M.A., Al-Ismail, K.M. (2005): Effect of heating and processing methods of milk and dairy products on conjugated linoleic acid and trans fatty acid isomer content. Journal of Dairy Science 88, 1301-1310. https://doi.org/10.3168/jds.S0022-0302(05)72796-X

15. Hoffmann, W., Kiesner, C., Clawin-Rädecker, I., Martin, D., Einhoff, K., Lorenzen, PC., Meisel, H., Hammer, P., Suhren, G., Teufel, P. (2006): Processing of extended shelf life milk using microfiltration. International Journal of Dairy Technology 59 (4), 229-235. https://doi.org/10.1111/j.1471-0307.2006.00275.x

16. IERiGŻ-PIB (2015): Milk market - condition and perspectives, Warsaw, September 2015.

17. Jensen, R.G. (1995): Handbook of milk composition. Academic Press, USA, pp. 544-545.

18. Kaufmann, V., Scherer, S., Kulozik, U. (2009): Stoffliche Veränderungen in Konsummilch durch haltbarkeitsverlängernde Verfahren. Deutsche Milchwirtschaft 60, 262-266.

19. Król, J., Brodziak, A., Litwińczuk, A. (2011): Basic chemical composition and content of selected whey proteins in milk from different cow breeds and in rennet whey. Żywność. Nauka. Technologia. Jakość 77, 74-83.

20. Lisak Jakopović, K., Barukčić, I., Božanić, R. (2016): Physiological significance, structure and isolation of $\alpha$-lactalbumin. Mljekarstvo 66 (1), 3-11.

21. Lorenzen, P.C., Clawin-Rädecker, I., Einhoff, K., Hammer, P., Hartmann, R., Hoffmann, W., Martin, D., Molkentin, J., Walte, H.G., Devrese, A. (2011): A survey of the quality of extended shelf life (ESL) milk in relation to HTST and UHT milk. International Journal of Dairy Technology 64 (2), 166-178. https://doi.org/10.1111/j.1471-0307.2010.00656.x
22. Martin, N.H., Ranieri, M.L., Wiedmann, M., Boor, K.J. (2012): Reduction of pasteurization temperature leads to lower bacterial outgrowth in pasteurized fluid milk during refrigerated storage: a case study. Journal of Dairy Science 95 (1), 471-475. https://doi.org/10.3168/jds.2011-4820

23. Mayer, H., Raba, B., Meier, J., Schmid, A. (2009): Extended shelf life (ESL) milk - milk with excessive heat load? European Dairy Magazine 21, 18-22.

24. Mika-Mętel, M. (2010): Analysis of changes in the quality of milk during storage. In Selected issue of food quality, (J. Żuchowski and R. Zieliński, eds.). Wydawnictwo Naukowe Instytutu Technologii Ekspolatacji, Radom, pp. 136-142.

25. Mittal, S., Bajwa, U. (2014): Effect of heat treatment on the storage stability of low calorie milk drinks. Journal of Food Science and Technology 51, 1875-1883. https://doi.org/10.1007/s13197-012-0714-z

26. Moatsou, G. (2010): Indigenous enzymatic activities in ovine and caprine milks. International Journal of Dairy Technology 63, 16-31. https://doi.org/10.1111/j.1471-0307.2009.00552.x

27. Pappas, C.S., Sakkas, L., Moschopoulou, E., Moatsou, G. (2015): Direct determination of lactulose in heat-treated milk using diffuse reflectance infrared Fourier transform spectroscopy and partial least squares regression. International Journal of Dairy Technology 68 (3), 448-453. https://doi.org/10.1111/1471-0307.12233

28. Pereda, J., Ferragut, V., Quevedo, J.M., Guamis, B., Trujillo, A.J. (2008): Effects of ultra-high-pressure homogenization treatment on the lipolysis and lipid oxidation of milk during refrigerated storage. Journal of Agricultural and Food Chemistry 56, 7125-7130. https://doi.org/10.1021/jf800972m

29. Pestana, J.M., Gennari, A., Monteiro, B.W., Lehn, D.N., De Souza, C.F.V. (2015): Effects of pasteurization and ultra-high temperature processes on proximate composition and fatty acid profile in bovine milk. American Journal of Food Technology 10, 265-272. https://doi.org/10.3923/ajft.2015.265.272

30. PN-68/A-86122. Milk. Research methods.

31. PN-A-86003/Al:1998. Milk and dairy products Drinking milk.

32. PN-EN ISO 4833-2:2013-12. Microbiology of the food chain - Horizontal method for the enumeration of microorganisms. Part 2: Colony count at $30^{\circ} \mathrm{C}$ by the surface plating technique.

33. Rodriguez-Alcala, L.M., Harte, F., Fontecha, J. (2009): Fatty acid profile and CLA isomers content of cow, ewe and goat milks processed by high pressure homogenization. Innovative Food Science and Emerging Technologies 10 (1), 32-36. https://doi.org/10.1016/j.ifset.2008.10.003 
34. Sadooghy-Saraby, S. (2011): Assessment of the entrapment of free fatty acids in goat milk by $\beta$-cyclodextrin and reduction of goaty flavor. A thesis is submitted to AUT University in partial fulfillment of the requirements for the degree of Master of Applied Science (MAppSc).

35. Sakkas, L., Moutafi, A., Moschopoulou, E., Moatsou, G. (2014): Assessment of heat treatment of various types of milk. Food Chemistry 159, 293-301. https://doi.org/10.1016/j.foodchem.2014.03.020

36. Siddique, F., Anjum, FM., Huma, N., Jamil, A. (2010): Effect of different UHT processing temperatures on ash and lactose content of milk during storage at different temperatures. International Journal of Agricultural and Biological Engineering 12, 439-442.

37. Sorhaug, T., Stepaniak, L. (1997): Psychrotrophs and their enzymes in milk and dairy products: Quality aspects. Trends in Food Science \& Technology 8, 35-40. https://doi.org/10.1016/S0924-2244(97)01006-6
38. Szpakowska, M., Tymoszuk, E. (2011): Investigation of UHT milk freshness after every day opening of its container, during storage in cooling conditions. Zeszyty Naukowe Uniwersytetu Ekonomicznego w Poznaniu 196, 162-169.

39. Vasbinder, A.J., Alting, A.C., De Kruif, K.G. (2003): Quantification of heat-induced casein-whey protein interactions in milk and its relation to gelation kinetics. Colloids and Surfaces B: Biointerfaces 31, 115-123. https://doi.org/10.1016/S0927-7765(03)00048-1

40. Ye, A., Singh, H., Oldfield, D.J., Anema, S.G. (2004): Kinetics of heat induced association of $\beta$-lactoglobulin and $\alpha$-lactalbumin with milk fat globule membrane in whole milk. International Dairy Journal 14, 389-398. https://doi.org/10.1016/j.idairyj.2003.09.004 